\title{
Calcium handling in porcine coronary endothelial cells by gastrin-17
}

\author{
E Grossini, C Molinari, L Sigaudo, M Biella, D A S G Mary and G Vacca
}

Laboratory of Physiology and Experimental Surgery, Department of Translational Medicine, Biotechnology Centre for Applicated Medical Research (BRMA), University of East Piedmont 'A. Avogadro', via Solaroli 17, AOU Maggiore della Carità, Corso Mazzini 36, I-28100 Novara, Italy

Correspondence should be addressed to E Grossini Email grossini@med.unipmn.it

\begin{abstract}
In porcine coronary artery endothelial cells (PCAEC), gastrin-17 has recently been found to increase nitric oxide (NO) production by the endothelial NO synthase (eNOS) isoform through cholecystokinin 1/2 (CCK 1/2) receptors and the involvement of protein kinase $A$ (PKA), PKC and the $\beta_{2}$-adrenoreceptor-related pathway. As eNOS is the $\mathrm{Ca}^{2+}$-dependent isoform of the enzyme, we aimed to examine the effects of gastrin-17 on $\mathrm{Ca}^{2+}$ movements. Thus, experiments were performed in Fura-2-acetoxymethyl-ester-loaded PCAEC, where changes of cytosolic $\mathrm{Ca}^{2+}\left(\left[\mathrm{Ca}^{2+}\right]_{c}\right)$ caused by gastrin-17 were analysed and compared with those of $\mathrm{CCK}$ receptors and $\beta_{2}$-adrenoreceptors agonists/antagonists. In addition, some experiments were performed by stimulating cells with gastrin-17 in the presence or absence of CAMP/PKA activator/inhibitor and of phospholipase $\mathrm{C}(\mathrm{PLC})$ and $\mathrm{Ca}^{2+}$-calmodulin dependent protein kinase II (CaMKII) blockers. The results have shown that gastrin-17 can promote a transient increase in $\left[\mathrm{Ca}^{2+}\right]_{\mathrm{c}}$ mainly originating from an intracellular pool sensitive to thapsigargin and from the extracellular space. In addition, the response of cells to gastrin-17 was increased by the adenylyl cyclase activator and the $\beta_{2}$-adrenoreceptor agonists and affected mainly by the CCK2 receptor agonists/antagonists. Moreover, the effects of gastrin-17 were prevented by $\beta_{2}$-adrenoreceptors and CaMKII blockers and the adenylyl cyclase/PKA and PLC inhibitors. Finally, in PCAEC cultured in $\mathrm{Na}^{+}$-free medium or loaded with the plasma membrane $\mathrm{Ca}^{2+}$ pump inhibitor, the gastrin-17-evoked $\mathrm{Ca}^{2+}$ transient was long lasting. In conclusion, this study shows that gastrin-17 affected intracellular $\mathrm{Ca}^{2+}$ homeostasis in PCAEC by both promoting a discharge of an intracellular pool and by interfering with the operation of store-dependent channels through mainly CCK2 receptors and PKA/PLC- and CaMKII-related signalling downstream of $\beta_{2}$-adrenoreceptor stimulation.
\end{abstract}

\section{Key Words}

- CCK receptors

- endothelial cells

- gastrin-17

- intracellular stores

\section{Introduction}

The gastrointestinal peptide hormone gastrin- 17 has been recently found in anaesthetized pigs to cause vasodilation through mechanisms related to nitric oxide (NO) effects (Grossini et al. 2011). NO measurement and protein analysis performed in porcine coronary artery endothelial cells (PCAEC) have shown an acute and dose-dependent endothelial NO synthase (eNOS)-related NO production
Journal of Molecular Endocrinology (2013) 50, 243-253 in response to gastrin-17, which was modulated by $\beta_{2}$-adrenoreceptor agonists/antagonists and was mainly related to a cAMP/protein kinase A (PKA) pathway. Moreover, although both cholecystokinin (CCK) receptors were found to be involved, the subtype 2 of CCK receptors was shown to play the most important role in such effects (Grossini et al. 2012). 
Changes of cytosolic $\mathrm{Ca}^{2+}\left(\left[\mathrm{Ca}^{2+}\right]_{c}\right)$ levels are of primary importance in the regulation of $\mathrm{NO}$ production. It is well known that the constitutive isoform of NOS present in endothelial cells (eNOS) is $\mathrm{Ca}^{2+}$ dependent (Lowenstein et al. 1994, Mizuno et al. 2000). eNOS is inactive until $\left[\mathrm{Ca}^{2+}\right]_{\mathrm{c}}$ increases, the $\mathrm{Ca}^{2+}$-binding protein binds to $\mathrm{Ca}^{2+}$ and the $\mathrm{Ca}^{2+}$-calmodulin complex activates eNOS (Moncada et al. 1991). The dynamic steady state of $\mathrm{Ca}^{2+}$ in the cytosol is the result of the balance between active and passive fluxes through the cell membranes and is strictly regulated (Munaron 2006). Transient fluctuations in $\left[\mathrm{Ca}^{2+}\right]_{c}$ may occur following inhibition of $\mathrm{Ca}^{2+}$ ATPases located in the plasma membrane or in the membrane of non-mitochondrial stores and activation of the release from intracellular stores may occur whether or not it is dependent on inositol1,4,5-triphosphate-phosphate (IP3) generation. Also, the release of intracellular $\mathrm{Ca}^{2+}$ coupled to subsequent $\mathrm{Ca}^{2+}$ entry (Putney 1990), known as 'capacitative $\mathrm{Ca}^{2+}$ entry', is a mechanism widely reported to affect $\mathrm{Ca}^{2+}$ homeostasis in response to both receptor-mediated stimuli (Putney 1990, Schilling et al. 1992, Fasolato \& Nilius 1998) and receptor-independent emptying of intracellular stores by agents such as thapsigargin, cyclovirobuxine D and urocortin II (Putney 1990, Schilling et al. 1992, Fasolato \& Nilius 1998, Grossini et al. 2005, 2010). In addition, the restoration of basal intracellular $\mathrm{Ca}^{2+}$ levels would play an important role by the activation of the plasma membrane $\mathrm{Ca}^{2+}$-ATPase (PMCA) pump and of $\mathrm{Na}^{+} / \mathrm{Ca}^{2+}$ exchanger (NCX; Moccia et al. 2002, Wang et al. 2002).

Changes of $\left[\mathrm{Ca}^{2+}\right]_{c}$ have been reported to be also crucial for the response of gastrointestinal cells to CCK receptor agonists. Hence, $\mathrm{Ca}^{2+}$ is an essential signalling molecule in gastrin-17-stimulated cell proliferation (Olszewska-Pazdrak et al. 2004) and is involved in gastrin-induced histamine secretion (Shibata et al. 2006). In addition, in isolated pig parietal cells, both gastrin-17 and the synthetic peptide pentagastrin increased $\left[\mathrm{Ca}^{2+}\right]_{\mathrm{c}}$ in a dose-dependent manner (Cabero et al. 1989). Also, the CCK receptor agonists, CCK58 and CCK8, have been found to either cause transient oscillatory $\left[\mathrm{Ca}^{2+}\right]_{\mathrm{c}}$ increases or sustained responses depending on whether CCK receptor agonists were used in physiological or supraphysiological concentrations in murine isolated pancreatic acinar cells (Criddle et al. 2009). The above effects on $\mathrm{Ca}^{2+}$ movements have been generally reported to be related to either $\mathrm{Ca}^{2+}$ entry from the extracellular space through CCK receptor stimulation (Criddle et al. 2009) and/or PKC and IP3-dependent opening of intracellular stores (Zanner et al. 2002, Olszewska-Pazdrak et al. 2004). In addition, involvement of MEK $1 / 2$ and ERK $1 / 2$ pathways has been reported (Olszewska-Pazdrak et al. 2004).

Thus, with the above considerations and as an extension of earlier works from our group showing an effect of gastrin-17 on NO production, the aim of this study was to investigate in PCAEC the effects of gastrin-17 on $\left[\mathrm{Ca}^{2+}\right]_{\mathrm{c}}$ handling and the mechanisms involved.

\section{Materials and methods}

Experiments were performed in primary culture cells, PCAEC, which were isolated from coronary arteries of anaesthetized pigs, as described previously (Grossini et al. 2009). The cells were plated into $0.1 \%$ gelatincoated culture dish by endothelial growth media-2 (EGM-2; EGM-2 BulletKit (CC-3124); Lonza, Inc., Basel, Switzerland) with the addition of human epidermal growth factor, hydrocortisone, gentamycin-amphotericin-B 1000, 2\% foetal bovine serum (FBS), vascular endothelial growth factor, human fibroblast growth factor-basic, recombinant analogue insulin-like growth factor 1-human, ascorbic acid, heparin (Lonza) and 1\% penicillin-streptomycin-glutamine (Sigma-Aldrich) and maintained in incubator at $37^{\circ} \mathrm{C}$ and $5 \% \mathrm{CO}_{2}$.

After $72 \mathrm{~h}, 10 \mathrm{ml}$ fresh medium was added and the incubation continued for $48 \mathrm{~h}$. After this time, the cells formed a monolayer and were subcultured. The cells used for the experiments were obtained from passages 3 to 5 .

Cells $\left(1 \times 10^{5}\right)$ were plated in $0.1 \%$ gelatin-coated 24-well plates in complete medium for $24 \mathrm{~h}$ and then maintained with DMEM (Sigma) 0\% FBS supplemented with $1 \%$ penicillin-streptomycin-glutamine (Sigma) without red phenol (starvation medium) for 4-6 h.

Some experiments were repeated in human coronary artery endothelial cells (HCAEC; Lonza) cultured in EGM-2. Experiments were performed with cells from passages 5 to 8 . At confluence, cells were serum starved for $6 \mathrm{~h}$ in endothelial cell basal medium (Lonza). HCAEC $\left(1 \times 10^{5}\right)$ were plated as described for PCAEC and then maintained in starvation medium for about $6 \mathrm{~h}$.

\section{Fura-2 fluorescence measurement of $\left[\mathrm{Ca}^{2+}\right]_{\mathrm{c}}$}

In the first set of experiments, the measurement of $\left[\mathrm{Ca}^{2+}\right]_{\mathrm{c}}$ was performed in cells grown to confluence, washed twice with sterile PBS $1 \times($ Sigma) and incubated with Fura-2/acetoxymethyl (AM) ester (5 $\mu \mathrm{M}$ final concentration, Sigma) for $30 \mathrm{~min}$ in the dark in DMEM (Sigma) $0 \%$ FBS and without red phenol. In some samples, cells

Published by Bioscientifica Ltd. 
were incubated in zero $\mathrm{Na}^{+}$-poly(sodium styrene sulphonate) (PSS) ( $N$-methyl-D-glucamine $126 \mathrm{mM}, \mathrm{KCl}$ $1.5 \mathrm{mM}, \mathrm{MgCl}_{2} 1.2 \mathrm{mM}$, HEPES $10 \mathrm{mM}$, D-glucose $10 \mathrm{mM}$ and $\mathrm{CaCl}_{2} 1 \mathrm{mM}$, Sigma). After further washing with DMEM (Sigma), the coverslips were mounted in agitation at $37^{\circ} \mathrm{C}$ in thermostated quartz couvette in a Hitachi F-4500 Fluorescence Spectrometer (Hitachi High-Technologies Corporation) operating continuously for $300 \mathrm{~s}$ at the wavelength pair $340 \mathrm{~nm}$ excitation/510 nm emission. Gastrin-17 (Tocris Bioscience, Bristol, UK) was added to Fura-2/AM-loaded cells, in the presence or absence of $\mathrm{Ca}^{2+}$ in the incubated medium (obtained with $50 \mathrm{mM}$ EGTA, Sigma). In some experiments, the effects of gastrin-17 were compared with those elicited by the CCK1 receptor agonists, sulphated CCK8 (Tocris) and A71378 (Tocris), or the CCK2 receptor agonist, pentagastrin (Sigma), which were administrated either alone or in co-stimulation with gastrin-17. The above agents were given at the final concentration of $10 \mathrm{pM}$ or, in the dose-response study, at final concentrations of $10^{-14}-10^{-6} \mathrm{M}$. In some experiments, the effects of gastrin17 were compared with those elicited by thapsigargin $(1 \mu \mathrm{M}$, Sigma), ATP (10 $\mu \mathrm{M}$, Sigma) and thrombin $(0.5 \mathrm{U} / \mathrm{ml}$, Sigma), which were administrated either before or after gastrin-17. Moreover, in some samples, agents were given before gastrin-17; they included the adenylyl cyclase blocker $2^{\prime} 5^{\prime}$-dideoxyadenosine ( $1 \mu \mathrm{M}$, Sigma; for $\left.15 \mathrm{~min}\right)$, the selective cAMP-dependent PKA inhibitor H89 $(1 \mu \mathrm{M}$, Sigma; for $15 \mathrm{~min}$ ), the phospholipase C (PLC) $\gamma$ inhibitor U73122 (1 $\mu \mathrm{M}$, for $30 \mathrm{~min}$, Sigma), the CCK1 receptors inhibitor lorglumide (50 $\mu \mathrm{M}$, Sigma; for $30 \mathrm{~min}$ ), the CCK2 receptor inhibitor CAM-1028 (15 $\mu \mathrm{M}$, Sigma; for $30 \mathrm{~min})$, the $\mathrm{Ca}^{2+}$-calmodulin-dependent protein kinase II (CaMKII) inhibitor KN-93 ( $1 \mu \mathrm{M}$, Sigma; for $15 \mathrm{~min})$, the PMCA pump blocker, carboxyeosin diacetate $(25 \mu \mathrm{M}$, Invitrogen; for $15 \mathrm{~min}$ ) and the $\beta_{2}$-adrenoreceptor antagonist, butoxamine (100 $\mu \mathrm{M}$, Sigma; for $15 \mathrm{~min}$ ). Finally, in some experiments, the effects of the adenylyl cyclase activator, forskolin ( $1 \mu \mathrm{M}$, Sigma), and the $\beta_{2}$-adrenoreceptor non-selective and selective agonists isoproterenol and zinterol (10 $\mu \mathrm{M}$, Sigma) respectively, given alone or in co-administration with gastrin-17 on $\left[\mathrm{Ca}^{2+}\right]_{\mathrm{c}}$, were analysed.

In the second set of experiments, the effects of gastrin-17 on the 'capacitative' $\mathrm{Ca}^{2+}$ entry through the plasma membrane $\mathrm{Ca}^{2+}$ channels were examined. Briefly, the cells on coverslips pre-treated with EGTA $(50 \mathrm{mM}$, Sigma) were subsequently exposed to thapsigargin $(1 \mu \mathrm{M})$ and gastrin-17 $(1 \mu \mathrm{M})$ alone or in combination for $5 \mathrm{~min}$. Finally, $60 \mathrm{mM} \mathrm{CaCl}_{2}$ was added to the different samples and the effects on 'capacitative' $\mathrm{Ca}^{2+}$ entry were analysed.
Quantification of $\left[\mathrm{Ca}^{2+}\right]_{\mathrm{c}}$ was obtained conventionally, as previously reported (Grynkiewicz et al. 1985, Grossini et al. 2010) using the following equation:

$\left(\mathrm{Ca}^{2+}\right)=K_{\mathrm{d}}\left(\left(R-R_{\min }\right) /\left(R_{\max }-R\right)\right)$.

The $K_{\mathrm{d}}$ of Fura-2/AM for $\mathrm{Ca}^{2+}$ was taken as $224 . R_{\min }$ and $R_{\max }$ were the minimum and the maximum values of fluorescence ratio obtained in $\mathrm{Ca}^{2+}$-free (EGTA $0.1 \mathrm{M}$ ) and $\mathrm{Ca}^{2+}$-saturated conditions. The fluorescence intensities obtained were corrected for cell autofluorescence at the wavelengths employed (Grynkiewicz et al. 1985).

\section{Statistical analyses}

All results were obtained from five different cell cultures for each experimental protocol. Student's paired $t$-test was used to examine the effects of each agent within each sample. Two-way ANOVA followed by Bonferroni's post hoc test were used for comparison among different experiments. A simple regression analysis was performed to examine the correlation between the concentration of administrated agents and the observed $\left[\mathrm{Ca}^{2+}\right]_{c}$ effects in the dose-response study. All data are presented as mean \pm s.D. A value of $P<0.05$ was considered statistically significant.

\section{Results}

The addition of gastrin-17 $\left(10^{-14}-10^{-6} \mathrm{M}\right)$ to a suspension of Fura-2/AM-loaded PCAEC (or HCAEC) in the presence of $\mathrm{Ca}^{2+}$ in the medium of incubation (Fig. 1) caused a rapid and transient dose-related increase in $\left[\mathrm{Ca}^{2+}\right]_{\mathrm{c}}$ reaching a peak effect after about $40 \mathrm{~s}$. The effects of gastrin-17 were lower than those caused by equimolar sulphated CCK8 and A71378 and particularly pentagastrin $(P<0.05$; Figs $1 \mathrm{~A}$ and 2A), which induced the highest response. In addition, the effects of gastrin-17 were increased when given in co-stimulation with either sulphated CCK8, A71378 or pentagastrin $(P<0.05$; Figs $1 \mathrm{~A}$ and $2 \mathrm{~B})$. A linear relationship was observed between the administrated concentrations of CCK receptor agonists and the effects on $\left[\mathrm{Ca}^{2+}\right]_{\mathrm{c}}(P<0.05)$. In PCAEC, therefore, gastrin-17 alone or in the presence of pentagastrin, sulphated CCK8 or A71378 respectively increased the $\left[\mathrm{Ca}^{2+}\right]_{\mathrm{c}}$ to $126.4 \pm 4.8,144.2 \pm 6.9$, $134.8 \pm 5.7$ and $134 \pm 4.5 \mathrm{nM}(P<0.05)$ from control values of about $111.4 \pm 2.4 \mathrm{nM}$ (Fig. $2 \mathrm{~B}$ ).

Moreover, as shown in Fig. 2C, the effects of gastrin-17 alone or in co-stimulation with equimolar pentagastrin, sulphated CCK8 or A71378 were significantly reduced

Published by Bioscientifica Ltd. 
A
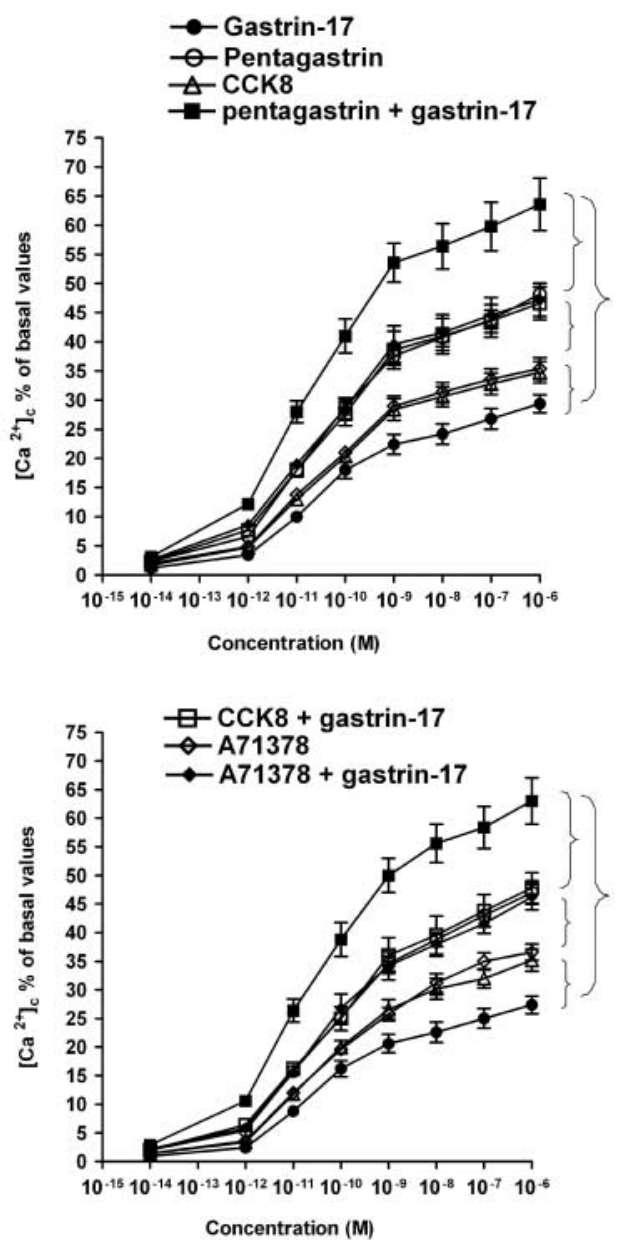

C

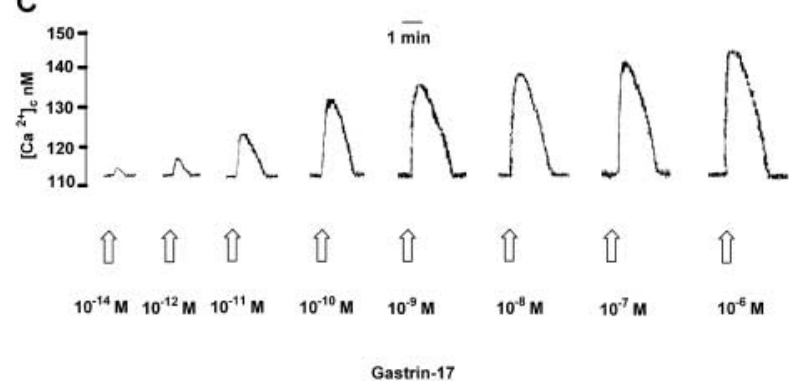

Figure 1

Concentration-dependent effects of gastrin-17 and other CCK receptor agonists on $\left[\mathrm{Ca}^{2+}\right]_{C}$ in Fura-2/AM-loaded coronary endothelial cells. In (A) and (B), the effects of gastrin-17, sulphated CCK8, pentagastrin and A71378 alone or in co-stimulation in PCAEC and HCAEC, are shown respectively. Reported data are means \pm s.D. $(n=5)$; CCK8, sulphated CCK8. In (C), an example showing the dose-response effects of gastrin-17 in PCAEC taken from one of the five different experiments for each experimental protocol.

in PCAEC cultured in $\mathrm{Ca}^{2+}$-free medium $(P<0.05)$. In PCAEC treated with EGTA, gastrin-17 alone or in the presence of pentagastrin, sulphated CCK8 and A71378 respectively increased the $\left[\mathrm{Ca}^{2+}\right]_{\mathrm{c}}$ to $105 \pm 2.8,111.2 \pm 4.6$,
$108.8 \pm 2.5$ and $108 \pm 2.1 \mathrm{nM}(P<0.05)$ from control values of about $100.2 \pm 1.5 \mathrm{nM}$. These results demonstrated that gastrin-17 mobilizes $\mathrm{Ca}^{2+}$ by both an extracellular milieu and intracellular stores (as suggested by the persistence of $\mathrm{Ca}^{2+}$ signal even in $\mathrm{Ca}^{2+}$-free medium).

As the effects of sulphated CCK8 were not different from those caused by A71378, in all successive experiments, sulphated CCK8 was used. Furthermore, for all successive experiments, the above agents were used at $10 \mathrm{pM}$, which was a similar concentration to the one that gradually increased NO release in PCAEC (Grossini et al. 2012). It is also noteworthy that this concentration was similar to serum gastrin-17 levels found in normal subjects (Grossini et al. 2012).

\section{Analysis of $\mathrm{Ca}^{2+}$ stores mobilized by gastrin-17}

In order to obtain more details on the nature of the intracellular store affected by gastrin-17, experiments were performed using extracellular ATP and thrombin, which mobilize $\mathrm{Ca}^{2+}$ from IP3-sensitive pools (Patel et al. 1999), and also thapsigargin, which is a powerful inhibitor of non-PMCAs (Thastrup et al. 1990, Gamberucci et al. 1994). As shown in Fig. $3 \mathrm{~A}$ and $\mathrm{B}$, in PCAEC, the amount of $\mathrm{Ca}^{2+}$ mobilized by either gastrin-17 $(10 \mathrm{pM}$ and $1 \mu \mathrm{M})$ or ATP $(10 \mu \mathrm{M})$ was significantly reduced when the agents were given in succession both in the absence or presence of EGTA $(P<0.05)$. By contrast, the amount of $\mathrm{Ca}^{2+}$ mobilized by either gastrin-17 $(1 \mu \mathrm{M})$ or thrombin $(0.5 \mathrm{U} / \mathrm{ml})$ did not significantly differ irrespective of the sequence of addition (Fig. 3C; $P>0.05$ ). Similar results were found in HCAEC (Supplementary Figure 1, see section on supplementary data given at the end of this article).

As depicted in Fig. 4, in PCAEC, the administration of thapsigargin $(1 \mu \mathrm{M})$ caused a persistent increase in $\left[\mathrm{Ca}^{2+}\right]_{\mathrm{c}}$ to levels of $155.8 \pm 3.2 \mathrm{nM}(P<0.05)$ from control values of $110.8 \pm 2.3 \mathrm{nM}$. When gastrin-17 was administrated before thapsigargin or in co-administration with thapsigargin, the kinetics of $\left[\mathrm{Ca}^{2+}\right]_{c}$ fluctuations promoted by thapsigargin was markedly changed. Hence, as shown in Fig. 4, when gastrin-17 $(10 \mathrm{pM}$ and $1 \mu \mathrm{M})$ was administrated before thapsigargin, the $\left[\mathrm{Ca}^{2+}\right]_{\mathrm{c}}$ reached peak values of $149.4 \pm 1.9$ and $130.4 \pm 7.6 \mathrm{nM}$ respectively, from similar control values as those reported earlier. Similar results were observed when gastrin-17 was given in co-stimulation with thapsigargin. The effects of thapsigargin in the presence of gastrin- 17 were statistically different from the one caused by thapsigargin alone $(P<0.05)$. Also in HCAEC, gastrin-17 $(1 \mu \mathrm{M})$ changed the response of cells to thapsigargin in a similar way to that

Published by Bioscientifica Ltd. 

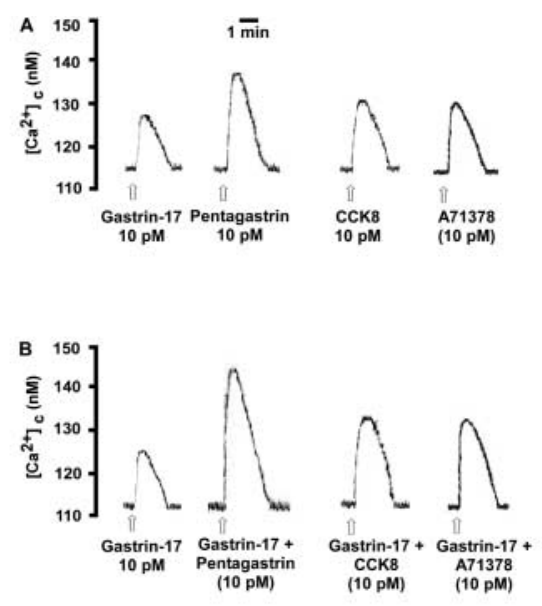

c
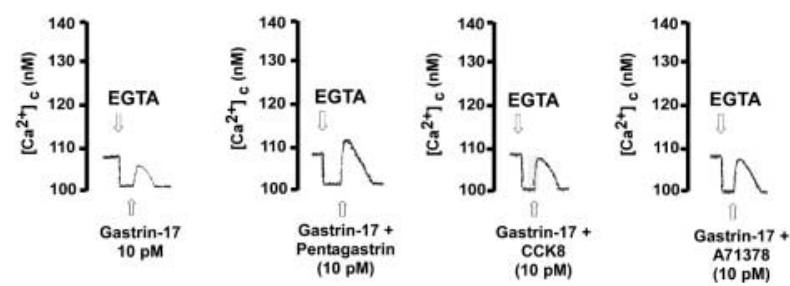

Figure 2

Effects of gastrin-17 and other CCK receptors agonists on $\left[\mathrm{Ca}^{2+}\right]_{\mathrm{c}}$ in Fura-2/AM-loaded PCAEC. In (A) and (B), gastrin-17 (10 pM), sulphated CCK8, pentagastrin and A71378 (10 pM) were administrated alone or in co-stimulation respectively. In (C), gastrin-17, sulphated CCK8, pentagastrin and $A 71378$ were administrated alone or in co-stimulation, in the presence of EGTA $(50 \mathrm{mM})$. In (A), (B) and (C), examples were taken from one of the five different experiments for each experimental protocol. The abbreviations are as in Fig. 1.

observed in PCAEC (Supplementary Figure 2A, see section on supplementary data given at the end of this article). These findings strongly support the conclusion that gastrin-17 mobilizes $\mathrm{Ca}^{2+}$ from a store that is depleted by thapsigargin treatment.

\section{Extracellular $\mathrm{Ca}^{2+}$ implications in gastrin-17-induced $\mathrm{Ca}^{2+}$ mobilization}

The depletion of thapsigargin-sensitive intracellular stores activates channels in the plasma membrane, which are permeable to $\mathrm{Ca}^{2+}$ (Fasolato et al. 1994, Berridge 1995). This phenomenon can be easily investigated through experiments aimed to analyse 'capacitative' $\mathrm{Ca}^{2+}$ entry. In PCAEC-treated gastrin-17 alone, the effects on $\mathrm{Ca}^{2+}$ handling observed after $\mathrm{Ca}^{2+}$ re-admission were not different from those previously observed. Moreover, in PCAEC treated with thapsigargin alone or in the presence of gastrin-17, the re-admission of $\mathrm{Ca}^{2+}$ in the incubation medium caused a $\mathrm{Ca}^{2+}$ increase amounting to $545 \pm 4$ and $543 \pm 3.4 \mathrm{nM}(P<0.05)$ respectively, from control values of $102.8 \pm 0.8$ and $101.8 \pm 2.4 \mathrm{nM}$. The $\mathrm{Ca}^{2+}$ increase caused by the concomitant administration of the two substances was not statistically different from the one caused by thapsigargin alone. An example of these findings taken from one of the five different experiments performed in PCAEC is depicted in Fig. 5A and B. Similar results were found in HCAEC (Supplementary Figure 2B).

As the NCX and PMCA have been shown to contribute to lower $\left[\mathrm{Ca}^{2+}\right]_{\mathrm{c}}$ in vascular endothelial cells (Moccia et al. 2002, Wang et al. 2002), experiments were performed to abolish their contribution to $\mathrm{Ca}^{2+}$ extrusion. As depicted in Fig. 5C, in PCAEC cultured in $\mathrm{Na}^{+}$-free medium, the gastrin-17 (10 pM and $1 \mu \mathrm{M})$-evoked $\mathrm{Ca}^{2+}$ increase was lower and had not returned to control values at $5 \mathrm{~min}$ from the start of gastrin-17 administration; the peak
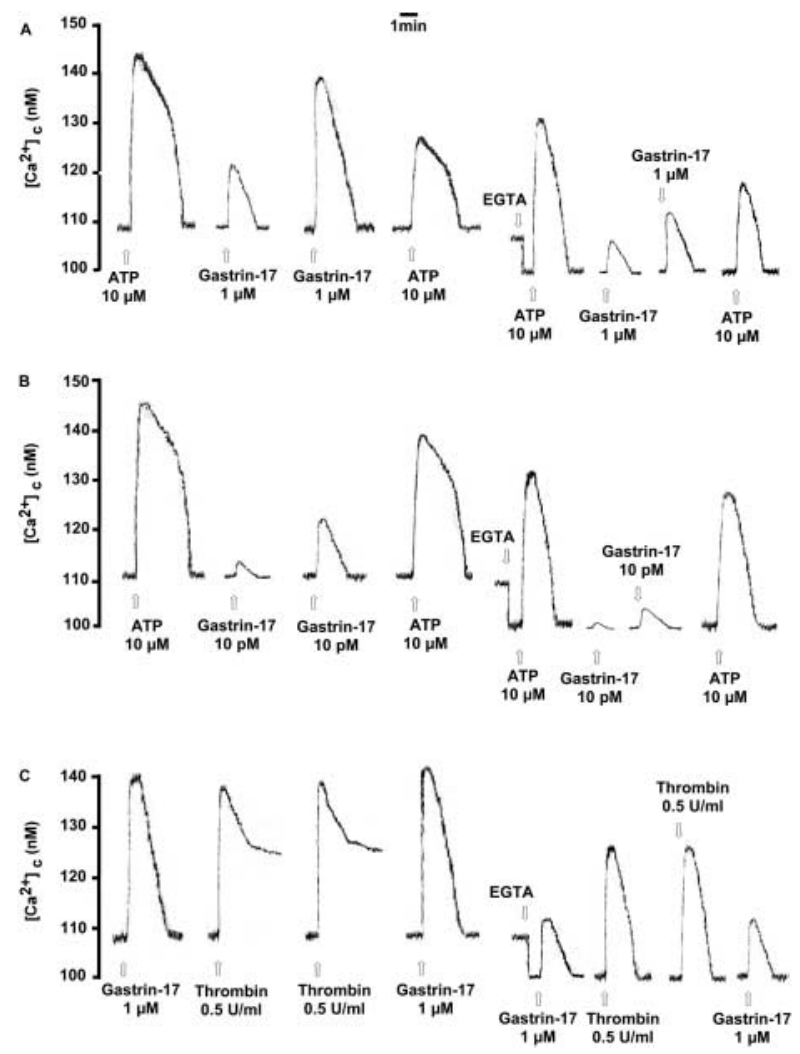

Figure 3

Analysis of intracellular $\mathrm{Ca}^{2+}$ stores mobilized by gastrin-17 in Fura-2/AMloaded PCAEC. In (A) and (B), gastrin-17 ( $1 \mu \mathrm{M}$ and $10 \mathrm{pM})$ was given before/after $10 \mu \mathrm{M}$ ATP either in the absence or presence of EGTA. In (C), gastrin-17 $(1 \mu \mathrm{M})$ was given before/after $0.5 \mathrm{U} / \mathrm{ml}$ thrombin either in the absence or presence of EGTA. In (A), (B) and (C), examples were taken from one of the five different experiments for each experimental protocol. 

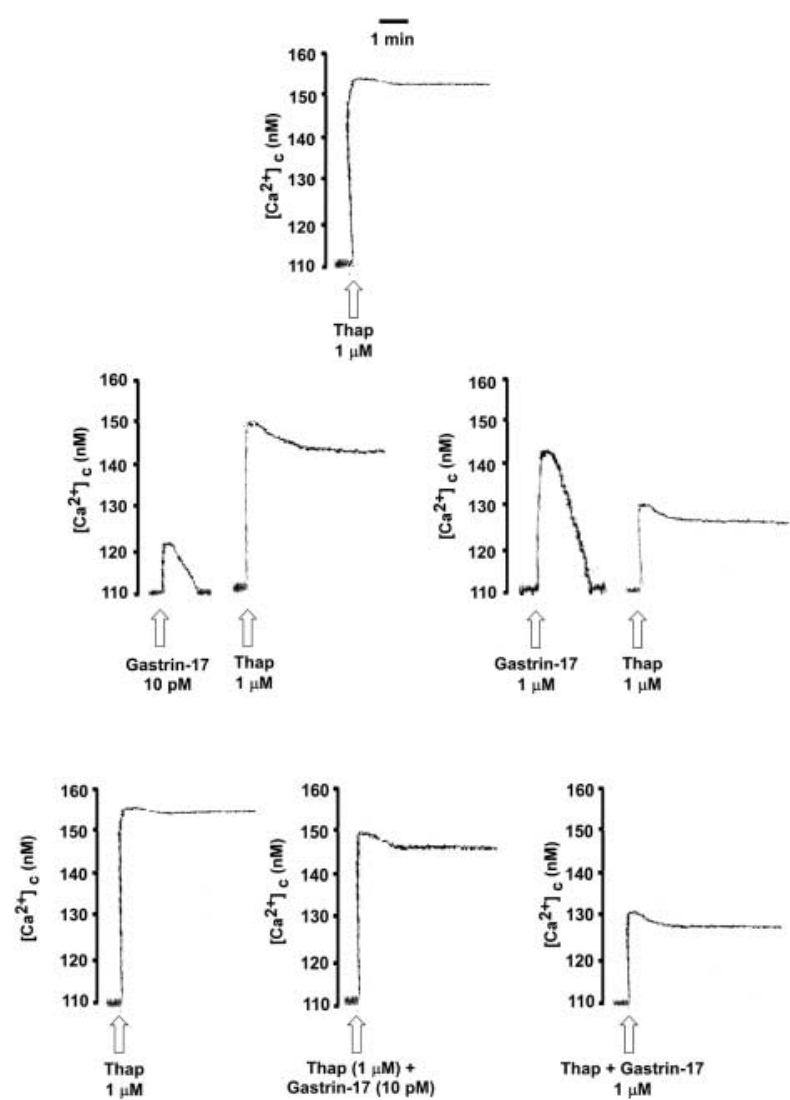

Figure 4

Modulation of thapsigargin-dependent $\left[\mathrm{Ca}^{2+}\right]_{\mathrm{C}}$ mobilization by gastrin-17 in Fura-2/AM-loaded PCAEC. Gastrin-17 (10 pM and $1 \mu \mathrm{M})$ was given before or in co-administration with thapsigargin $(1 \mu \mathrm{M})$. Examples were taken from one of the five different experiments for each experimental protocol. Thap, thapsigargin.

effect of gastrin-17 on $\left[\mathrm{Ca}^{2+}\right]_{\mathrm{c}}$ amounted to $121.6 \pm 3.5$ and $139.2 \pm 3.1 \mathrm{nM}(P<0.05)$ from control values of $111.4 \pm 2.7 \mathrm{nM}$. In PCAEC cultured in $\mathrm{Na}^{+}$-free medium and in the presence of the PMCA pump blocker carboxyeosin $(25 \mu \mathrm{M})$, the $\left[\mathrm{Ca}^{2+}\right]_{c}$ increase induced by gastrin-17 (10 pM and $1 \mu \mathrm{M})$, after peak effects of 120.4 \pm 2.3 and $140 \pm 1.6 \mathrm{nM}(P<0.05)$ respectively from control values of $110 \pm 1.6 \mathrm{nM}$, reached a plateau (Fig. 5C; $P<0.05$ ). Similar results were found in HCAEC (Supplementary Figure 2C).

\section{Mechanisms of action of $\mathrm{Ca}^{2+}$ mobilization}

To verify the involvement of the CCK1 and CCK2 receptors, $\beta_{2}$-adrenoreceptors, cAMP/PKA, PLC $\gamma$ and CaMKII pathways in $\mathrm{Ca}^{2+}$ movements caused by gastrin-17, experiments were performed in the presence of specific inhibitors/activators. In particular, PCAEC and HCAEC were treated with the CCK1 receptor antagonist lorglumide $(50 \mu \mathrm{M})$, the selective CCK2 receptor antagonist CAM-1028 $(15 \mu \mathrm{M})$, the $\beta_{2}$-adrenoreceptor non-selective and selective agonists, isoproterenol $(10 \mu \mathrm{M})$ and zinterol $(10 \mu \mathrm{M})$, and antagonist, butoxamine $(100 \mu \mathrm{M})$, the adenylyl cyclase activator, forskolin $(1 \mu \mathrm{M})$, and blocker, $2^{\prime} 5^{\prime}$-dideoxyadenosine $(1 \mu \mathrm{M})$, the selective cAMP-dependent PKA inhibitor, H89 $(1 \mu \mathrm{M})$, the PLC $\gamma$ inhibitor, U73122 $(1 \mu \mathrm{M})$ and the CaMKII blocker, KN-93 $(1 \mu \mathrm{M})$. All the above agents were used in doses similar to those previously shown to affect the response of PCAEC to gastrin-17 (Grossini et al. 2012). Moreover, $50 \mu \mathrm{M}$ lorglumide and $15 \mu \mathrm{M}$ CAM-1028 were able to prevent the effects of $1 \mu \mathrm{M}$ sulphated CCK 8 and $1 \mu \mathrm{M}$ pentagastrin on $\mathrm{Ca}^{2+}$ movements in preliminary experiments performed in PCAEC.

The effects of various agents given alone on $\mathrm{Ca}^{2+}$ movements are reported in Table 1. As depicted in Fig. 6A, the response of PCAEC to gastrin-17 $(1 \mu \mathrm{M})$ was increased by isoproterenol, zinterol and forskolin by about 22, 23 and $32 \%$ respectively. It is also noteworthy that zinterol increased the effects of gastrin-17 when given in co-stimulation with pentagastrin to an extent greater than that with sulphated CCK8. In PCAEC treated with gastrin-17/pentagastrin/zinterol, the $\left[\mathrm{Ca}^{2+}\right]_{\mathrm{c}}$ amounted to $206 \pm 11.9 \mathrm{nM}$ from control values of $109 \pm 3.4 \mathrm{nM}$, whereas in the absence of zinterol, it amounted to $165.4 \pm 6.1 \mathrm{nM}$ from similar control values. In cells treated with gastrin-17/CCK8/zinterol, the $\left[\mathrm{Ca}^{2+}\right]_{\mathrm{c}}$ amounted to $174 \pm 7.4 \mathrm{nM}$ from control values of $108.2 \pm 3.2 \mathrm{nM}$, whereas in the absence of zinterol it amounted to $152.4 \pm 6.7 \mathrm{nM}$ from similar control values. In addition, CAM-1028 and lorglumide, which were able to decrease basal $\left[\mathrm{Ca}^{2+}\right]_{\mathrm{c}}$ (Table 1 ), caused a significant reduction of the response of cells to gastrin-17 when given separately and prevented the effects of gastrin-17 when given in co-stimulation (Fig. 6A).

Similarly, the effects of gastrin-17 were prevented by butoxamine, 2'5'-dideoxyadenosine, H89, U73122 and KN-93 (Fig. 6A and C). Similar results were obtained in HCAEC (Fig. 6B and D).

\section{Discussion}

This is the first study showing that gastrin-17 can cause transient increases in $\left[\mathrm{Ca}^{2+}\right]_{\mathrm{c}}$ in endothelial cells through the activation of CCK receptors and the involvement of the $\beta_{2}$-adrenoreceptor pathway and of cAMP/PKA-, PLC $\gamma$ - and CaMKII-related signalling.

Published by Bioscientifica Ltd. 
A

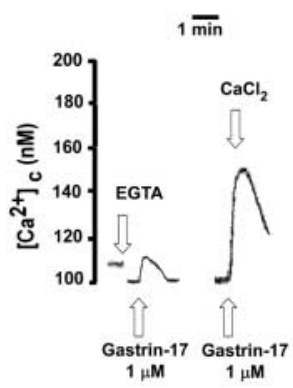

B
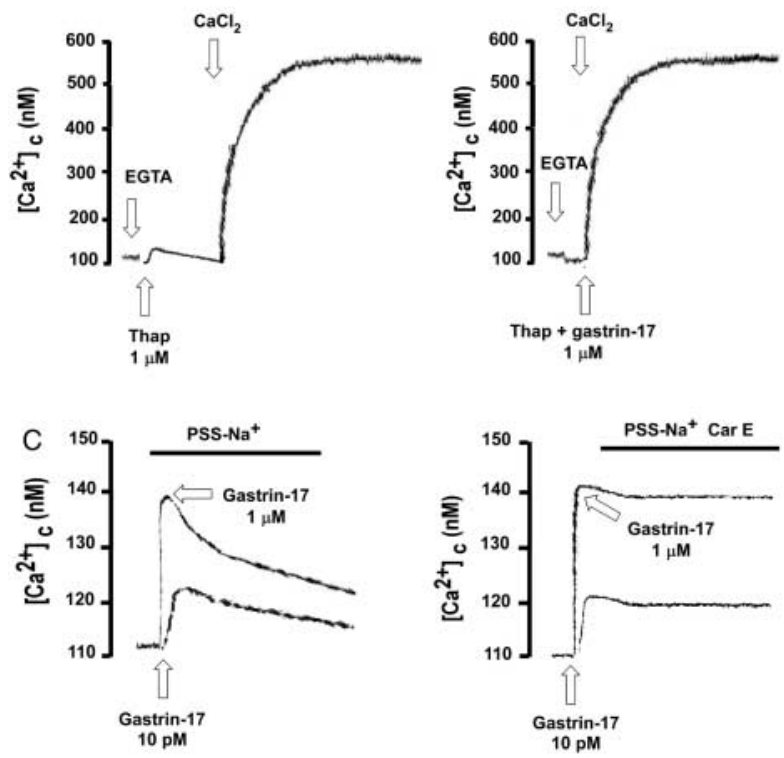

Figure 5

Effects of gastrin-17 on 'capacitative' $\mathrm{Ca}^{2+}$ entry, NCX and PMCA in Fura-2/AM-loaded PCAEC. In (A), cells pre-treated with EGTA were stimulated with gastrin-17 $(1 \mu \mathrm{M})$. The effects on $\mathrm{Ca}^{2+}$ movements were examined also with $\mathrm{CaCl}_{2}$ re-admission. In (B), cells pre-treated with EGTA were stimulated with thapsigargin $(1 \mu \mathrm{M})$ alone or in co-stimulation of gastrin-17 $(1 \mu \mathrm{M})$. The effects on $\mathrm{Ca}^{2+}$ movements were examined also with $\mathrm{CaCl}_{2}$ re-admission. Example was taken from one of the five different experiments for each experimental protocol. Abbreviation is as in Fig. 4. In (C), effects of gastrin-17 (10 pM and $1 \mu \mathrm{M})$ on $\left[\mathrm{Ca}^{2+}\right]_{c}$ in PCAEC incubated in PSS- $\mathrm{Na}^{+}$in the absence or presence of carboxyeosin $(25 \mu \mathrm{M})$. Example was taken from one of the five different experiments for each experimental protocol. Car E, carboxyeosin.

The dynamic steady state of $\left[\mathrm{Ca}^{2+}\right]_{\mathrm{c}}$ is the result of the balance between active and passive fluxes that affect the cytosol, intracellular stores and the extracellular environment. $\mathrm{Ca}^{2+}$ enters the cytosolic compartment by direct influx from the extracellular milieu through a variety of plasma membrane channels or from intracellular stores. Free $\left[\mathrm{Ca}^{2+}\right]_{\mathrm{c}}$ is maintained very low by $\mathrm{Ca}^{2+}$ pumps like the NCX located in the plasma membrane and by active pumps in the membrane of either mitochondrial or non-mitochondrial stores such as the endoplasmic reticulum that extrude $\mathrm{Ca}^{2+}$ from the cytosol by direct ATP consumption (Munaron 2006).
Intracellular $\mathrm{Ca}^{2+}$ concentration in endothelial cells plays an important role in regulating a variety of cellular functions, some of which are related to the production of NO by the constitutive $\mathrm{Ca}^{2+}$-dependent isoform of NOS, eNOS (Lowenstein et al. 1994). Many agents known to induce NO release by endothelial cells stimulate eNOS by increasing the $\left[\mathrm{Ca}^{2+}\right]_{\mathrm{c}}$, either by promoting $\mathrm{Ca}^{2+}$ release from intracellular stores and/or by enhancing $\mathrm{Ca}^{2+}$ influx from the extracellular compartment (Newby \& Henderson 1990, Buga et al. 1991, Moncada et al. 1991). It is noteworthy that the present results have shown for the first time that $\beta_{2}$-adrenoreceptor stimulation, which has been reported to increase endothelial NO release (Grossini et al. 2012), also augmented $\left[\mathrm{Ca}^{2+}\right]_{\mathrm{c}}$ in both human and porcine coronary endothelial cells.

In PCAEC, gastrin-17, at concentrations similar to those that increased NO production in the same cells (Grossini et al. 2012), was shown to cause a dosedependent increase in $\left[\mathrm{Ca}^{2+}\right]_{\mathrm{c}}$, which peaked at about $40 \mathrm{~s}$ and almost returned to basal level in about $60 \mathrm{~s}$. The fact that the response of cells to gastrin-17 was changed in the presence of EGTA and ATP but not by thrombin suggests that $\mathrm{Ca}^{2+}$ mobilized by gastrin-17 is partly of extracellular origin and partly from the same intracellular IP3-regulated pool mobilized by ATP, but different from that mobilized by thrombin. In addition, the findings obtained in the absence of EGTA would suggest the absence of effects of gastrin- 17 on the $\mathrm{Ca}^{2+}$-dependent stimulated $\mathrm{Ca}^{2+}$ influx from extracellular space, which has been reported to be caused by both ATP and thrombin (Ahmmed et al. 2004, Aromolaran \& Blatter 2005). Similar findings were also obtained in HCAEC, which confirmed the above results in PCAEC.

Table 1 Effects of various agents on $\mathrm{Ca}^{2+}$ movements in PCAEC. Values are means \pm s.D. (\%) of five independent experiments for each experimental protocol

\begin{tabular}{|c|c|}
\hline Sample & {$\left[\mathrm{Ca}^{2+}\right]_{\mathbf{c}}(\mathrm{nM})$} \\
\hline Control & $106.6 \pm 3.7$ \\
\hline Gastrin-17 (1 $\mu \mathrm{M})$ & $137.4 \pm 3.2$ \\
\hline Zinterol $(10 \mu \mathrm{M})$ & $136.8 \pm 4^{*}$ \\
\hline Isoproterenol $(10 \mu \mathrm{M})$ & $134.6 \pm 3.4 *$ \\
\hline Forskolin $(1 \mu \mathrm{M})$ & $136.2 \pm 2.3 *$ \\
\hline CAM-1028 $(15 \mu \mathrm{M})$ & $94.2 \pm 2.6 *$ \\
\hline Lorglumide $(50 \mu \mathrm{M})$ & $100 \pm 3.1^{*,+}$ \\
\hline Butoxamine $(100 \mu \mathrm{M})$ & $101 \pm 1.6^{*}$ \\
\hline $2^{\prime} 5^{\prime}$-Dideoxyadenosine $(1 \mu \mathrm{M})$ & $99.8 \pm 1.3^{*}$ \\
\hline $\mathrm{H} 89(1 \mu \mathrm{M})$ & $100.6 \pm 1.3 *$ \\
\hline U73122 (1 $\mu \mathrm{M})$ & $103 \pm \overline{3} .7$ \\
\hline $\mathrm{KN}-93(1 \mu \mathrm{M})$ & $103.8 \pm 4.5$ \\
\hline
\end{tabular}

${ }^{*} P<0.05$ vs control and ${ }^{\dagger} P<0.05$ vs CAM-1028. http://jme.endocrinology-journals.org DOI: 10.1530/JME-12-0148
C) 2013 Society for Endocrinology Printed in Great Britain 

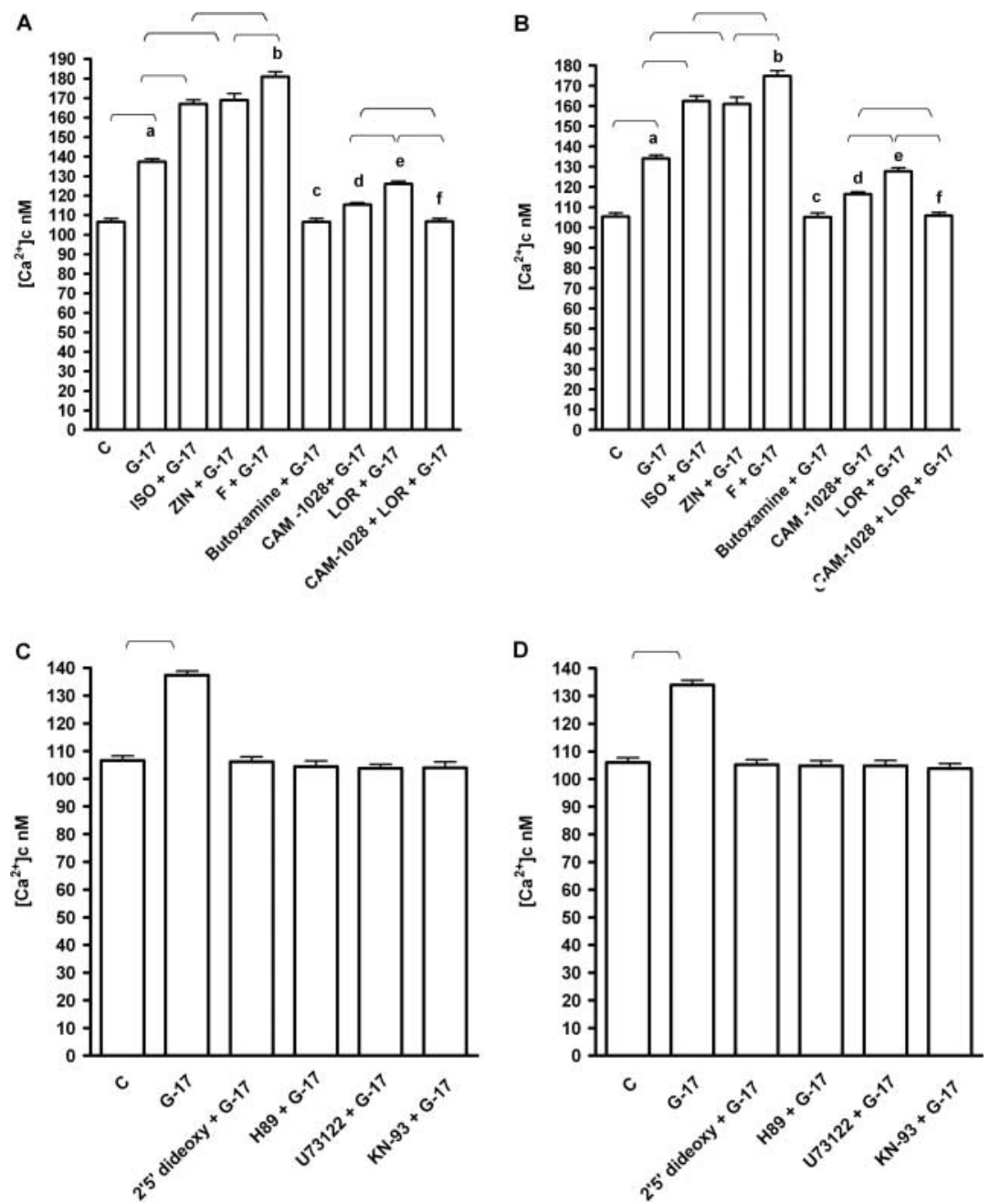

Figure 6

Effects of gastrin-17 and other $\mathrm{CCK}$ receptor agonists on $\left[\mathrm{Ca}^{2+}\right]_{\mathrm{C}}$ movements in the absence or presence of various agonists/antagonists. In (A) and (B), gastrin-17 was given alone or in co-administration with isoproterenol, zinterol, forskolin, butoxamine, CAM-1028 and lorglumide in PCAEC and HCAEC respectively. G-17, gastrin-17 $(1 \mu \mathrm{M})$; ISO, isoproterenol $(10 \mu \mathrm{M})$; ZIN, zinterol $(10 \mu \mathrm{M}) ; \mathrm{F}$, forskolin $(1 \mu \mathrm{M})$; butoxamine, butoxamine

The present results also showed that the intracellular pool depleted by gastrin-17 was the same as that of thapsigargin, the $\mathrm{Ca}^{2+}$-ATPase inhibitor that is able to deplete the endoplasmic reticulum $\mathrm{Ca}^{2+}$ pool (Thastrup et al. 1990, Gamberucci et al. 1994). By contrast, gastrin-17 did not affect the sustained increase in $\left[\mathrm{Ca}^{2+}\right]_{\mathrm{c}}$ promoted by thapsigargin, thus excluding the modulation of the so-called 'capacitative' opening of plasma membrane $\mathrm{Ca}^{2+}$ channels caused by thapsigargin (Toshima et al. 2000, Kwan et al. 2001).

The effects of gastrin- 17 on $\mathrm{Ca}^{2+}$ movements were less than those elicited by the CCK2 receptor-specific agonist

$(100 \mu \mathrm{M})$, CAM-1028, CAM-1028 $(15 \mu \mathrm{M})$; Lor, lorglumide $(50 \mu \mathrm{M}) . P<0.05$ : $b, c, d$, e and $f$ vs $a$. In (C) and (D), gastrin-17 was given alone or in co-administration with $2^{\prime} 5^{\prime}$-dideoxyadenosine, H89, U73122 and KN-93 in PCAEC and HCAEC respectively. 2' $5^{\prime}$-Dideoxy, $2^{\prime} 5^{\prime}$-dideoxyadenosine $(1 \mu \mathrm{M})$; H89, H89 (1 $\mu \mathrm{M})$; U73122, U73122 (1 $\mu \mathrm{M})$; KN-93, KN-93 (1 $\mu \mathrm{M})$. Abbreviations are as in (A) and (B). Reported data are means \pm s.D. $(n=5)$.

pentagastrin, which potentiated the response of cells to gastrin-17 to a higher extent than both non-selective and selective CCK1 receptor agonists, sulphated CCK8 and A71378 respectively (Grossini et al. 2012). It is also noteworthy that pre-treatment of cells with the CCK receptor inhibitors, particularly CAM-1028, caused a reduction of basal $\left[\mathrm{Ca}^{2+}\right]_{c}$, which confirmed a role for mostly CCK2 receptor in modulation of calcium movements in PCAEC. Moreover, in PCAEC and HCAEC pre-treated with lorglumide and above all CAM-1028, the effects of gastrin-17 were significantly reduced, being abolished by co-administration of the above blockers.

Published by Bioscientifica Ltd. 
These findings also confirmed the prevalent involvement of CCK2 receptors over CCK1 ones in the mechanism of action at the basis of gastrin-17-dependent $\left[\mathrm{Ca}^{2+}\right]_{\mathrm{c}}$ increase as well as previously reported observations (Rihab 1999, Grossini et al. 2011, 2012).

As shown by experiments performed in the presence of adenylyl cyclase agonist/antagonist, PKA/PLC and CaMKII inhibitors, the effects of gastrin-17 were found to be related to cAMP-PKA-PLC and CaMKII-dependent signalling. Hence, the effects of gastrin-17 were increased by forskolin and abolished by pre-treatment of PCAEC and HCAEC with $2^{\prime} 5^{\prime}$-dideoxyadenosine, H89, U73122 and $\mathrm{KN}-93$, which were given at similar concentrations to those previously used in the same cells (Grossini et al. 2012). These findings are in agreement with previous data showing that G protein-coupled CCK receptor agonists activate cAMP/PKA and PLC/PKC intracellular cascades (Noble et al. 1999, Kombian et al. 2006, Grossini et al. 2012).

In addition, the present results are in line with previous reports regarding the effects of CCK receptor agonists on $\mathrm{Ca}^{2+}$ movements and their related mechanisms of action. Hence, in isolated pig parietal cells, both gastrin-17 and pentagastrin increased $\left[\mathrm{Ca}^{2+}\right]_{\mathrm{c}}$ in a dose-dependent manner over the concentration range $10^{-9}-10^{-6} \mathrm{M}$ (Cabero et al. 1989). Also CCK8 increased $\left[\mathrm{Ca}^{2+}\right]_{\mathrm{c}}$ in porcine chief cells, mainly through the involvement of CCK1 receptors (Heim et al. 1995). Furthermore, in various cell lines, gastrin-17 stimulated the production of cAMP, phosphatidylinositol hydrolysis and mobilization of intracellular $\mathrm{Ca}^{2+}$ (Ishizuka et al. 1994).

In this context, it is noteworthy that the removal of extracellular $\mathrm{Ca}^{2+}$ in small-cell lung cancers did not affect the increase in $\left[\mathrm{Ca}^{2+}\right]_{\mathrm{c}}$ activated by gastrin, suggesting $\mathrm{Ca}^{2+}$ release from internal stores (Rihab 1999), which partly confirms findings obtained in this study.

Also the results obtained in the presence of specific $\beta_{2}$-adrenoreceptors agonists/antagonists are in agreement with findings previously observed in coronary endothelial cells (Grossini et al. 2012). Hence, the response of PCAEC to gastrin-17 was increased by the $\beta_{2}$-adrenoreceptors nonselective and selective agonists, isoproterenol and zinterol, and abolished by the specific inhibitor butoxamine; this confirmed the involvement of a $\beta_{2}$-adrenergic-related signalling in the intracellular pathway activated by gastrin-17. Although the role of the $\beta$-adrenergic system in the regulation of $\mathrm{Ca}^{2+}$ movements in myocytes is widely accepted (Kurokawa et al. 2002), the finding of a modulation of $\left[\mathrm{Ca}^{2+}\right]_{\mathrm{c}}$ in vascular endothelial cells of either porcine or human origin is quite new. In addition, these observations would suggest a rather preferential association of CCK2 over CCK1 receptors and $\beta_{2}$-adrenergic-related pathway in modulation of $\left[\mathrm{Ca}^{2+}\right]_{\mathrm{c}}$ mobilization in PCAEC and confirm previous findings about the existence of a preferential cross-reaction between the CCK2 receptor signalling cascade and $\beta_{2}$-adrenergic pathway in the same cellular model (Grossini et al. 2012). Hence, the response of cells to gastrin-17 plus pentagastrin was more augmented by co-stimulation with zinterol than that observed by gastrin-17 plus sulphated CCK8 in co-stimulation with zinterol. Although not clearly stated yet, the involvement of intracellular mediators downstream of CCK receptor and $\beta_{2}$-adrenoreceptor activation could be at the basis of the observed effect. Further experiments will be necessary to address this issue.

The return of $\left[\mathrm{Ca}^{2+}\right]_{\mathrm{c}}$ to control values was shown to be related to the activation of the PMCA pump and NCX activation, which are widely reported to restore the basal intracellular $\mathrm{Ca}^{2+}$ levels in endothelial cells (Moccia et al. 2002, Wang et al. 2002). Hence, in PCAEC and HCAEC cultured in $\mathrm{Na}^{+}$-free medium, the decay phase of the gastrin-17-evoked $\mathrm{Ca}^{2+}$ transient was significantly longer. Moreover, in PCAEC and HCAEC cultured in $\mathrm{Na}^{+}$-free medium and loaded with carboxyeosin, the specific PMCA pump inhibitor, the effects of gastrin-17 on $\left[\mathrm{Ca}^{2+}\right]_{\mathrm{c}}$ transient reached a plateau. Thus, the results obtained showed that during the decay phase of the $\mathrm{Ca}^{2+}$ transient, $\mathrm{Ca}^{2+}$ was extruded by both the PMCA pump and by NCX. Blocking the $\mathrm{Na}^{+}$-dependent and $\mathrm{Na}^{+}$-independent $\mathrm{Ca}^{2+}$ extrusion mechanisms has made the cells unable to extrude the $\mathrm{Ca}^{2+}$ released by the thapsigargin-sensitive and IP3-dependent pool following gastrin-17 stimulation.

In conclusion, in porcine and human coronary endothelial cells, gastrin-17 used in similar doses as those recently reported to cause eNOS activation through CCK receptors and cAMP/PKA, PLC and CaMKII-dependent signalling, transiently increased $\left[\mathrm{Ca}^{2+}\right]_{\mathrm{c}}$. At the basis of such an effect, there could be the CCK receptors CAMP/PKA- and PLC-dependent depletion of the thapsigargin-sensitive and IP3-dependent $\mathrm{Ca}^{2+}$ pool and $\left[\mathrm{Ca}^{2+}\right]_{\mathrm{c}}$ increase. In such signalling, the involvement of intracellular factors downstream of $\beta_{2}$-adrenoreceptor activation would play a role in modulating the response of PCAEC to gastrin-17. Moreover, the activation of both NCX and PMCA by gastrin- 17 would be implicated in restoring the basal $\left[\mathrm{Ca}^{2+}\right]_{\mathrm{c}}$.

\section{Supplementary data}

This is linked to the online version of the paper at http://dx.doi.org/10.1530/ JME-12-0148.

Published by Bioscientifica Ltd. 


\section{Declaration of interest}

The authors declare that there is no conflict of interest that could be perceived as prejudicing the impartiality of the research reported.

\section{Funding}

This research has received generous sponsorship by Università del Piemonte Orientale 'A. Avogadro' and by Regione Piemonte-Ricerca Sanitaria Finalizzata 2009.

\section{Acknowledgements}

The authors thank Vera Morsanuto and Roberto Ardizzoia for their help in data collection and examination and also thank to the Azienda Ospedaliera Maggiore della Carità di Novara for its help.

\section{References}

Ahmmed GU, Mehta D, Vogel S, Holinstat M, Paria BC, Tiruppathi C \& Malik AB 2004 Protein kinase $\mathrm{C} \alpha$ phosphorylates the TRPC1 channel and regulates store-operated $\mathrm{Ca}^{2+}$ entry in endothelial cells. Journal of Biological Chemistry 279 20941-20949. (doi:10.1074/jbc.M313975200)

Aromolaran AA \& Blatter LA 2005 Modulation of intracellular $\mathrm{Ca}^{2+}$ release and capacitative $\mathrm{Ca}^{2+}$ entry by CaMKII inhibitors in bovine vascular endothelial cells. American Journal of Physiology. Cell Physiology 289 C1426-C1436. (doi:10.1152/ajpcell.00262.2005)

Berridge MJ 1995 Capacitative calcium entry. Biochemical Journal 312 1-11. Buga GM, Gold ME, Fokuto JM \& Ignarro LJ 1991 Shear stress-induced release of nitric oxide from endothelial cells grown on beads. Hypertension 17 187-193. (doi:10.1161/01.HYP.17.2.187)

Cabero JL, Rehfeld JF \& Mårdh S 1989 The effects of various gastrins on intracellular free $\mathrm{Ca}^{2+}$ in isolated pig parietal cells. Acta Physiologica Scandinavica 136 301-307. (doi:10.1111/j.1748-1716.1989.tb08670.x)

Criddle DN, Booth DM, Mukherjee R, McLaughlin E, Green GM, Sutton R, Petersen OH \& Reeve JR 2009 Cholecystokinin-58 and cholecystokinin8 exhibit similar actions on calcium signaling, zymogen secretion, and cell fate in murine pancreatic acinar cells. American Journal of Physiology. Gastrointestinal and Liver Physiology 297 G1085-G1092. (doi:10.1152/ ajpgi.00119.2009)

Fasolato C \& Nilius B 1998 Store depletion triggers the calcium releaseactivated calcium current (ICRAC) in macrovascular endothelial cells: a comparison with Jurkat and embryonic kidney cell lines. Pflügers Archiv: European Journal of Physiology 436 69-74. (doi:10.1007/s004240050605)

Fasolato C, Innocenti B \& Pozzan T 1994 Receptor-activated $\mathrm{Ca}^{2+}$ influx: how many mechanisms for how many channels? Trends in Pharmacological Sciences 15 77-83. (doi:10.1016/0165-6147(94)90282-8)

Gamberucci A, Innocenti B, Fulceri R, Banhegyi G, Giunti R, Pozzan T \& Benedetti A 1994 Modulation of $\mathrm{Ca}^{2+}$ influx dependent on store depletion by intracellular adenine-guanine nucleotide levels. Journal of Biological Chemistry 269 23597-23602.

Grossini E, Avanzi G, Gallicchio M, Molinari C, Vacca G \& Bellomo G 2005 Regulation of $\mathrm{Ca}^{2+}$ movements by cyclovirobuxine D in ECV304 endothelial cells. Pharmacological Research 52 154-161. (doi:10.1016/j. phrs.2005.01.003)

Grossini E, Molinari C, Caimmi PP, Uberti F \& Vacca G 2009 Levosimendan induces NO production through p38 MAPK, ERK and Akt in porcine coronary endothelial cells: role for mitochondrial K(ATP) channel. British Journal of Pharmacology 156 250-261. (doi:10.1111/j.1476-5381. 2008.00024.x)

Grossini E, Caimmi PP, Molinari C, Mary DA, Uberti F \& Vacca G 2010 Modulation of calcium movements by urocortin II in endothelial cells.
Cellular Physiology and Biochemistry 25 221-232. (doi:10.1159/ 000276556)

Grossini E, Caimmi P, Molinari C, Uberti F, Mary D \& Vacca G 2011 Intracoronary gastrin 17 increases cardiac perfusion and function through autonomic nervous system, CCK receptors, and nitric oxide in anesthetized pigs. Journal of Applied Physiology 110 95-108. (doi:10.1152/japplphysiol.00625.2010)

Grossini E, Caimmi P, Molinari C, Uberti F, Mary D \& Vacca G 2012 CCK receptors-related signaling involved in nitric oxide production caused by gastrin 17 in porcine coronary endothelial cells. Molecular and Cellular Endocrinology 350 20-30. (doi:10.1016/j.mce.2011.11.018)

Grynkiewicz G, Poenie M \& Tsien RY 1985 A new generation of $\mathrm{Ca}^{2+}$ indicators with greatly improved fluorescence properties. Journal of Biological Chemistry 260 3440-3450.

Heim HK, Elhöft A, Wittstock H \& Sewing KF 1995 Characterization of CCK receptor-mediated effects on intracellular calcium of porcine chief cells. Journal of Physiology and Pharmacology 46 489-501.

Ishizuka J, Townsend CM Jr, Bold RJ, Martinez J, Rodriguez M \& Thompson JC 1994 Effects of gastrin on 3',5'-cyclic adenosine monophosphate, intracellular calcium, and phosphatidylinositol hydrolysis in human colon cancer cells. Cancer Research 54 2129-2135.

Kombian SB, Ananthalakshmi KV, Parvathy SS \& Matowe WC 2006 Cholecystokinin-2 receptors couple to cAMP-protein kinase A to depress excitatory synaptic currents in rat nucleus accumbens in vitro. Canadian Journal of Physiology and Pharmacology 84 203-211. (doi:10.1139/y05-119)

Kurokawa H, Murray PA \& Damron DS 2002 Propofol attenuates $\beta$-adrenoreceptor-mediated signal transduction via a protein kinase C-dependent pathway in cardiomyocytes. Anesthesiology 96 688-698. (doi:10.1097/00000542-200203000-00027)

Kwan CY, Leung YM, Kwan TK \& Daniel EE 2001 Tetrandrine inhibits $\mathrm{Ca}^{2+}$ release activated $\mathrm{Ca}^{2+}$ channels in vascular endothelial cells. Life Sciences 68 841-847. (doi:10.1016/S0024-3205(00)00988-7)

Lowenstein CJ, Dinerman JL \& Snyder SH 1994 Nitric oxide: a physiologic messenger. Annals of Internal Medicine 120 227-237.

Mizuno O, Kobayashi S, Hirano K, Nishimura J, Kubo C \& Kanaide H 2000 Stimulus-specific alteration of the relationship between cytosolic $\mathrm{Ca}^{2+}$ transients and nitric oxide production in endothelial cells ex vivo. British Journal of Pharmacology 130 1140-1146. (doi:10.1038/ sj.bjp.0703420)

Moccia F, Berra-Romani R, Baruffi S, Spaggiari S, Signorelli S, Castelli L, Magistretti J, Taglietti V \& Tanzi F $2002 \mathrm{Ca}^{2+}$ uptake by the endoplasmic reticulum $\mathrm{Ca}^{2+}$-ATPase in rat microvascular endothelial cells. Biochemical Journal 364 235-244.

Moncada S, Palmer RM \& Higgs EA 1991 Nitric oxide: physiology, pathophysiology and pharmacology. Pharmacological Reviews $\mathbf{4 3}$ 109-142.

Munaron L 2006 Intracellular calcium, endothelial cells and angiogenesis. Recent Patents on Anti-Cancer Drug Discovery 1 105-119. (doi:10.2174/ 157489206775246502)

Newby AC \& Henderson AH 1990 Stimulus secretion coupling in vascular endothelial cells. Annual Review of Physiology 52 661-674. (doi:10.1146/ annurev.ph.52.030190.003305)

Noble F, Wank SA, Crawley JN, Bradwejn J, Seroogy KB, Hamon M \& Roques BP 1999 International Union of Pharmacology. XXI. Structure, distribution, and functions of cholecystokinin receptors. Pharmacological Reviews 51 745-781.

Olszewska-Pazdrak B, Ives KL, Park J, Townsend CM Jr \& Hellmich MR 2004 Epidermal growth factor potentiates cholecystokinin/gastrin receptormediated $\mathrm{Ca}^{2+}$ release by activation of mitogen-activated protein kinases. Journal of Biological Chemistry 279 1853-1860. (doi:10.1074/ jbc.M309481200)

Patel S, Joseph SK \& Thomas AP 1999 Molecular properties of inositol 1,4,5-triphosphate receptors. Cell Calcium 25 247-264. (doi:10.1054/ ceca.1999.0021) 
Putney JW Jr 1990 Capacitative calcium entry revisited. Cell Calcium 11 611-624. (doi:10.1016/0143-4160(90)90016-N)

Rihab R 1999 Signaling pathways mediating gastrin's growth-promoting effects. Peptides 20 885-898. (doi:10.1016/S0196-9781(99)00077-7)

Schilling WP, Cabello OA \& Rajan L 1992 Depletion of the inositol 1,4,5-trisphosphate-sensitive intracellular $\mathrm{Ca}^{2+}$ store in vascular endothelial cells activates the agonist-sensitive $\mathrm{Ca}^{2+}$ influx pathway. Biochemical Journal 284 521-530.

Shibata N, Matsui H, Yokota T, Matsuura B, Maeyama K \& Onji M 2006 Direct effects of nitric oxide on histamine release from rat enterochromaffin-like cells. European Journal of Pharmacology 535 25-33. (doi:10.1016/j.ejphar.2006.01.058)

Thastrup O, Cullen PJ, Droback MR, Hanley MR \& Dawson AP 1990 Thapsigargin a tumor promoter, discharges intracellular $\mathrm{Ca}^{2+}$ stores by specific inhibition of the endoplasmic reticulum $\mathrm{Ca}^{2+}$-ATPase. PNAS 87 2466-2470. (doi:10.1073/pnas.87.7.2466)

Toshima JY, Hirano K, Nishimura J, Nakano H \& Kanaide H 2000 Differential effects of progesterone and $17 \beta$ estradiol on the $\mathrm{Ca}^{2+}$ entry induced by thapsigargin and endothelin-1 in in situ endothelial cells. Biochimica et Biophysica Acta 1499 109-121. (doi:10.1016/S01674889(00)00112-9)

Wang X, Reznick S, Li P, Liang W \& van Breemen C $2002 \mathrm{Ca}^{2+}$ removal mechanisms in freshly isolated rabbit aortic endothelial cells. Cell Calcium 31 265-277. (doi:10.1016/S0143-4160(02)00075-1)

Zanner R, Hapfelmeier G, Gratzl M \& Prinz C 2002 Intracellular signal transduction during gastrin-induced histamine secretion in rat gastric ECL cells. American Journal of Physiology. Cell Physiology $\mathbf{2 8 2}$ C374-C382.

Received in final form 10 December 2012

Accepted 24 January 2013

Accepted Preprint published online 24 January 2013
Published by Bioscientifica Ltd. 